varied accounts of themselves that the independence of the testimony cannot be doubted. That its work is popular is indicated by the wish expressed by one of them that "there should be a National Bureau." Factory legislation is printed in it (even I884 legislation, although the printer's date is 1883 !) ; the factory inspector has become a popular institution, and much testimony is borne to the smaller hardship of factory laws uniformly than loosely enforced. The more educated and more prosperous workmen are, the more ambitious and aspiring they become, and we seem on the eve of their blending with their masters when complaints are made, as here, that many of their fellow-workmen are satisfied with only 66 shillings a week wages; and a caution is held forth to such not to spend their money in foolishly aping the rich.

Yet, though the teacher here is no longer one of the fatherly governments of the old world using his paternal authority for the good of a rather refractory son, yet the teaching is most satisfactorily similar. Drunkenness could not be set forth as the prevailing cause of pauperism among the men or the evil of a lack of artistic taste among the masters in more vivid or unqualified terms than they arehere. The sad combination of progress and poverty is bewailed, but we fear that co-operation urged here as its remedy too much overlooks the control of fashion and its effect upon supply and demand. A most practical power put in the hands of this Bureau is that of examining the accounts of co-operative companies. Any five members of a company may require such an examination.

The principal industries of New Jersey are taken, and, after full statistics of their amount, prosperity and prospects, with the wages earned by each class of workers, an interesting account is given, commencing with a short history of the methods, improvements, and general position of the trade in the United States and in other countries, and their experience compared. Any one casting about for an occupation in which he could take a satisfactory part would find in this "Book of Trades" much to supply the information first required, and much to encourage him. Among them we find a review of the silk trade, which, under the ægis of 60 per cent. duty, has made the wealthy city of Paterson; of glass-making, which at present does not extend much beyond window glass and bottles; of the cultivation of sorghum, still in its infancy in New Jersey; and of the pottery trade-after its account of which it performs the very useful function of a publication like this of appealing to such a trade to take the steps necessary for raising their standard of art. An appeal is made, not from a Government department, or from an interfering clique as South Kensington is occasionally regarded as being, but by the organ of his late fellow-workers, that the maker of one of those large fortunes so common in America will, for his country's glory and their help, found a technical school; while hands are led to feel that intellectual training and not mechanical energy alone is wanted. The idea is shown here also to be making its way that the school should be made the basis of technical as well as of mental training; that the dextrous use of the body should form part of the school, as well as of the playground, teaching. More than this, it is felt that they should not be two so distinct branches of education as in past days, and that the members and muscles of the body, as well as the brain, should receive elementary instruction at the school, and that the former should be placed more deliberately under the control of the latter. It is felt in America that

"The cultured mind

The skilful hand"

ought naturally to go together, and not that one should be the usual mark of the absence of the other; that, therefore, a mechanic should not mean little more than a machine, but a mechanician, able to understand, make or repair the giant body that is using its limbs to save his exertions, and therefore a man more on a level with other men whose time has been given to the cultivation of their minds only, and more justified in insisting upon their equality with the latter. It is urged in this Report that elementary technical knowledge valuable to all the New Jersey trades may be given in ordinary schools; that technical learning is popular, frequently most so to boys who are slow at books; and that successful manual occupation improves the morality of the worst of such boys.

A very favourable notice of the Reformatory school at Coldwater; a sad tale of jail arrangements, and of methods of keeping the poor, all lead to discussions of economical difficulties felt long ago in England, not by any means avoided in America, and showing how little forms of government can modify human nature. A more hopeful view of that is afforded by the account, illustrated with three engravings and three plans, of a working-man's Institute at Millville. At this one establishment, which seems to have cost little more than $4000 l$, are combined, besides large grounds used for field sports, bicycling, \&c., a gymnasium and baths in charge of a barber in the basement, while on the ground floor are a conversation room hung round with maps and supplied with musical instruments on which performances are given, where also lectures are delivered, discussions held, and games of skill played. Side by side with it is a library and reading-room. Up stairs are four class-rooms and a large hall seating 500 persons, besides a gallery over the rear half of it. At the other end of it is a stage with two dressing-rooms and other necessary adjuncts. This room is used on Sundays as well as on weekdays by various societies--a choral class among others-and is a convenient source of revenue.

It is impossible to lay down our Report without feeling that if each department of its work is by itself of little importance, it will doubtless be a useful agent in making every inhabitant of New Jersey and of the United States a more intelligent worker at his trade or surveyor of the economies around him.

\section{PIERCING THE ISTHMUS OF PANAMA}

THREE years ago the work of cutting through the Panama isthmus had barely commenced. The equatorial forests on the neck of land, 73 kilometres long, which marked the axis of the future interoceanic canal, had hardly been laid bare. The traveller who followed the primitive road met here and there some groups of cabins, with roofs of branches on poles, marking the site of a sounding or the improvised dwellings of a portion of the operators. Culebra, Emperador, Corosita, and Gamboa, which are now full of activity, were then almost desert, and on the coast of Colon alone the excavator traced in the marshy plains of Gatun his great track. The contrast to-day is great: a long file of workshops covers the space between the Atlantic and the Pacific. Twenty thousand workmen toil on the Cordillera, making the deep cutting for the canal. Side by side with this army, another more powerful army of colossal machines, excavators, dredges, locomotives, waggons, all the materials for transport, thousands of pairs of wheels, hundreds of kilometres of rails, mountains of coal, and shiploads of dynamite. Among the twenty-five workshops of the peninsula the attention is chiefly attracted to two points: the great rocky cutting at Culebra, which is to penetrate to a depth of 120 metres into the Cordillera, and the dam of the Chagres at Gamboa. At Culebra the previsions of M. de Lesseps have been realised: the mountainous mass which the canal will traverse is, for the most part, composed of rocks which are not very hard; repeated soundings by means of diamond perforators have shown that down to a

\footnotetext{
1 Abstract from La Nature.
} 
considerable depth the rock takes the form of schists in horizontal strata. There is no doubt that it can be cut through with rapidity ; it is a matter of perforation, either by mining and ordinary explosives, or by shafts with larger quantities of some explosive to displace great masses. Here 30,000 cubic metres of rock have been displaced by an explosion of dynamite; and unquestionably this colossal channel connecting two seas may be executed by simple methods and with economy.

At the end of the great cutting of Culebra, 6 kilometres from Emperador, is the great workshop for the dam across the Chagres. This gigantic basin, containing about $1,000,000,000$ cubic metres of water, the surface of which is 60 metres above the water of the canal, has a bank, the content of which is 7,000,000 cubic metres. The volume of water kept in by this exceeds a hundredfold that of any reservoir in the world. By means of this work inundations in the river are prevented, currents impeding navigation and introducing rough water into the canal are avoided, and there is no fear of the accumulation of alluvion in the bed. By regulating the flow of the Chagres and of the neighbouring streams, the dam at Gamboa assures the regular service of the canal. The method of constructing this work of proportions without precedent in the annals of public works is a very simple one. From the great cutting at Culebra, near Gamboa, and the neighbouring cuttings, about 50,000,000 cubic metres of rock are removed, while only about $7,000,000$ are required for the Chagres dam, and therefore the work is one of transport only-a colossal one, it is true. Even the site of the dam is formed naturally by the disposition of the bed of the torrent, which is contracted at this place between the hills of Obispo and Santa Cruz, which are distant about I 50 metres from each other, and on which will rest the front wall of the great reservoir. Behind this first barrier will be thrown, as they are taken from the Cordillera, the $7,000,000$ metres of rock, and the dam will be complete. The originality of the project is that, strictly speaking, there is no masonry at all in this enormous mass of rock of all sizes and shapes; the accumulation alone gives the mass firmness. The plan given here enables us to follow the sinuous course of the Chagres River. Like all torrents, and especially all torrents in equatorial regions, it is subject to considerable variations in its flow, and to enormous and violent floods. In winter its flow is 1600 cubic metres per second, while in spring it is barely 13 metres. Its tributaries, or rios, are of the same character-the rio Trinidad and the rio Gatuncillo have a flow in winter of 400 cubic metres. It would be impossible to divert these impetuous masses of water into the canal without producing currents and deposits and impeding the navigation. The overflow of exceptional floods will be conducted to the sea by secondary water courses. These latter, which vary in breadth from 8 to I2, and even to 40 metres near the Atlantic, are easily made by utilising the portions of the bed of the river situated on the same bank, and connecting them by appropriate trenches. The enormous reserve behind the dam will flow regularly in this new bed. Of course, the bed of the canal will be completely protected from these deviating waters, in the trenches by the slopes of the latter, and in the lower parts by banks which will soon be covered by a vigorous and indestructible tropical vegetation. With the construction of this reservoir, assured by the clearings from the cutting, and the water regulated and controlled by these courses, the work, like that of the cutting at Culebra, is only one of time. One objection which was raised when the public became acquainted with the almost incredible magnitude of the work, in which a reservoir becomes a great lake, was that this latter might itself be filled up with the alluvial deposits, which it was constructed to keep out of the canal. It is true that in its tropical floods the Chagres carries along a large quantity of alluvion; but this, which would be an insuperable obstacle in the canal, becomes a secondary consideration in the reservoir. It has been calculated by the chief engineer to the work that the Chagres can bring into the lake in a thousand years $30,000,000$ cubic metres of alluvion, while the cubic content of the lake is $1,000,000,000$ cubic metres.

Culebra and the dam at Gamboa have always been the two principal points, the main obstacles to the canal. But there are thirty-five other principal working stations, all connected with the railway between Colon and Panama. As the illustration shows, they are sufficiently near to each other to be considered uninterrupted. Fifty excavators and ten dredges work at the canal. Up to the twenty-fifth kilometre we mreet with dredges, at first at Colon for the port, then at Gatun. As far as the Panama Plain there are more than sixty excavators. In the three workshops at Culebra are now installed the contractors who cut the canal from Amsterdam to the North Sea. At Corosal, at the sixtieth kilometre, the great port for access to the canal from the Pacific is to be placed, and there the great American dredges work in the swampy ground. It has been calculated that the work done up to the present is half that required to complete the undertaking, and that this new maritime route to the East will be opened in 1888 .

The work stands at present in this position: it involves in all the movement of about $100,000,000$ cubic metres of rocks of varying consistency. Of this, $70,000,000$ are to be raised, according to the contracts, in successive instalments in 1885 , I886, and 1887 . The remaining $30,000,000$, which form the actual canal, will be raised at the expiration of this time either by the same contractors or by new ones. Knowing the amount already raised, the contract periods for raising a certain other quantity and the amount remaining to be done at the end of the present contracts, we can, by a sum in simple proportion, calculate when the whole should be completed. In 1888 it should be ready for traffic. 7 his simple programme could only be applied to a work so colossal after a long and laborious period of minute study and preparation. The period of installation is always the most important in all these vast enterprises: the study and command of the appropriate material, the reception, testing, arrangement of the machines, the construction of the workshops, accommodation for the workmen, \&c. ; it is only when all these have been completed, when all have been made ready for work and tested, that the real work can commence, and that progress becomes sensible. This period of installation lasted, for example, in the case of the St. Gothard tunnel, for fifteen months; but the Panama canal calls for ten times more capital than the tunnel, it is executed in a country which has first to be cleared of a luxuriant tropical jungle, thousands of miles away from all industrial centres. The preparation for this gigantic work under these circumstances was a most important fraction of the work, and it is the opinion of competent men that what has actually been done during the installation period now brought to a close is equivalent to half of the work necessary to achieve the canal. In the case of the Suez Canal, 70,000,000 cubic metres had to be raised; of these, 50,000,000 were raised in two years after the apparatus had been put in working order. Seventy million cubic metres must be raised by the drags and excavators of the twenty-one principal contractors; $18,000,000$ are to be raised by August $I$ of the current year. These 2 I contracts represent an outlay of about $240,000,000$ francs, of which $65,000,000$ have been tendered by French contractors; $55,000,000$ by Americans ; $20,000,000$ by Italian, Swiss, Swedish, and natives, and $90,000,000$ by an Anglo-Dutch Company. All nations are working therefore at the task. The French contractors are at work at the cutting at Emperador; the Anglo-Dutch Company has to remove 13,000,000 cubic metres in the great cutting at Culebra. Practically 
the whole isthmus is being attacked simultaneously. Fig. 4 represents the work at the station of Emperador. It is connected by rails, on which locomotives run with other stations, and with the ColonPanama Railway. The material taken out is conveyed to the great dam, which is to keep in the water of the Chagres River. The cutting at Emperador is 200 metres wide in.certain places. Next to this comes the great station of Culebra. These two stations are represented in the accompanying sketches. While all this work of dredging and excavating, making cuttings and embankments is going on at the canal, the two ports of entry on the Atlantic and the Pacific are being constructed. At Colon, powerful dredging works are opened. A pier, protected on the western side by a mole, has been built, on which a new town, Christopher Columbus, is growing. On it are placed the workshops, stores, railway stations, \&c. All the constructions are connected with the rail-

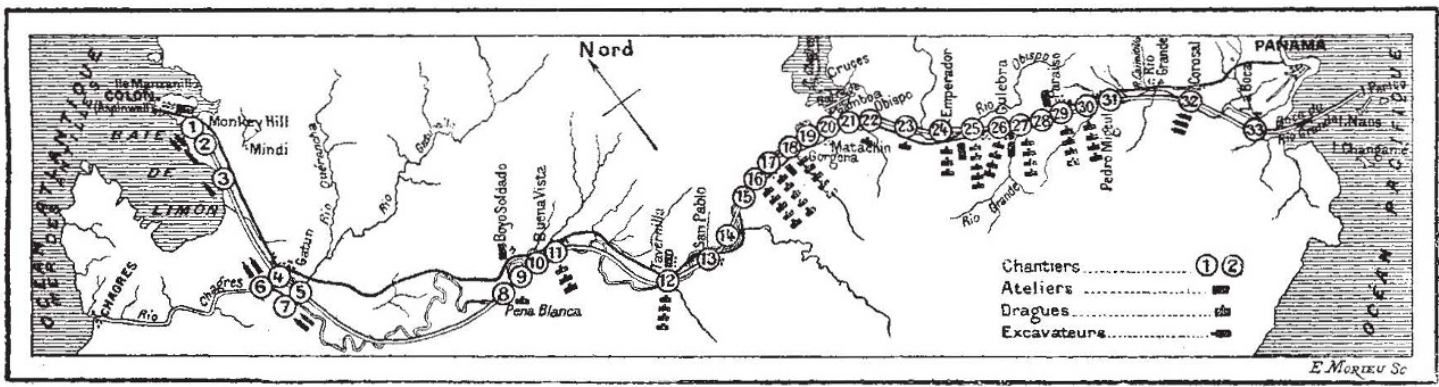

FIG. x.-Line of Canal and works in ccurse of execution. 1, 2, dredgings of the Port of Colon ; 3, 4, 5, dredgings between Colon and Gatun ; 6, 7, deviation of Ric Trinidad at Gatun ; 8, dockyard of Pena Blanca ; 9, ro, embankment of Bohio Saldado ; 11, Buena Vista ; 12, Tavernilla ; 13, I4, San Pablo ; I5, 16, 17, Ot Emperador; 25, El Lirio ; 26, 27, 28. La Culebra ; 29, 30, Paraiso ; 31, Pedro Miguel ; 32, Corosal; 33, Boca Grande.

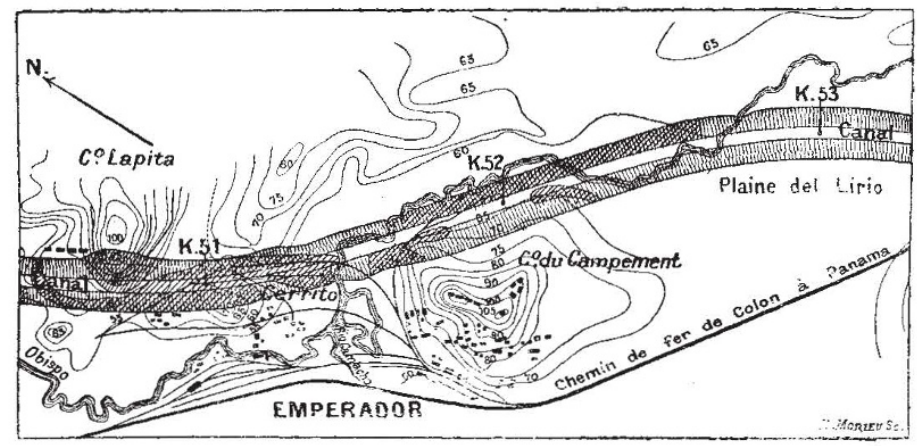

Fig. 2.-Emperador Docks.

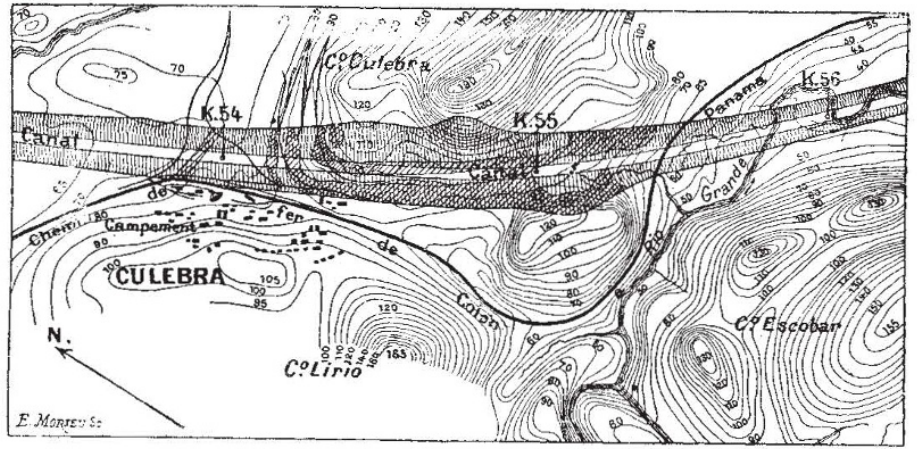

FIG. 3.-Culebra Docks.

way across the isthmus by a series of branches. Vessels drawing any amount of water can discharge at the wharf projecting into the sea, and completely protected from the wind. On the Pacific coast, the creation of a port at the mouth of the Rio Grande presents no technical difficulties, and six dredges are now at work making a channel Ioo metres in width to the sea. A special organisation has been created to deal with the vast material, its employment, and repair. The isthmus has been divided into three sections, with a centre at Matachin, at the foot of the great embankment and the cutting. Here all the material is concentrated, all the repairs executed, and all the machinery put in working order. The railway of the isthmus is now the property of the Canal Company, and facilitates greatly this movement of the machinery on which the regular working of the various sections depends. By its means each working station is in communication with the central one and with every other. 


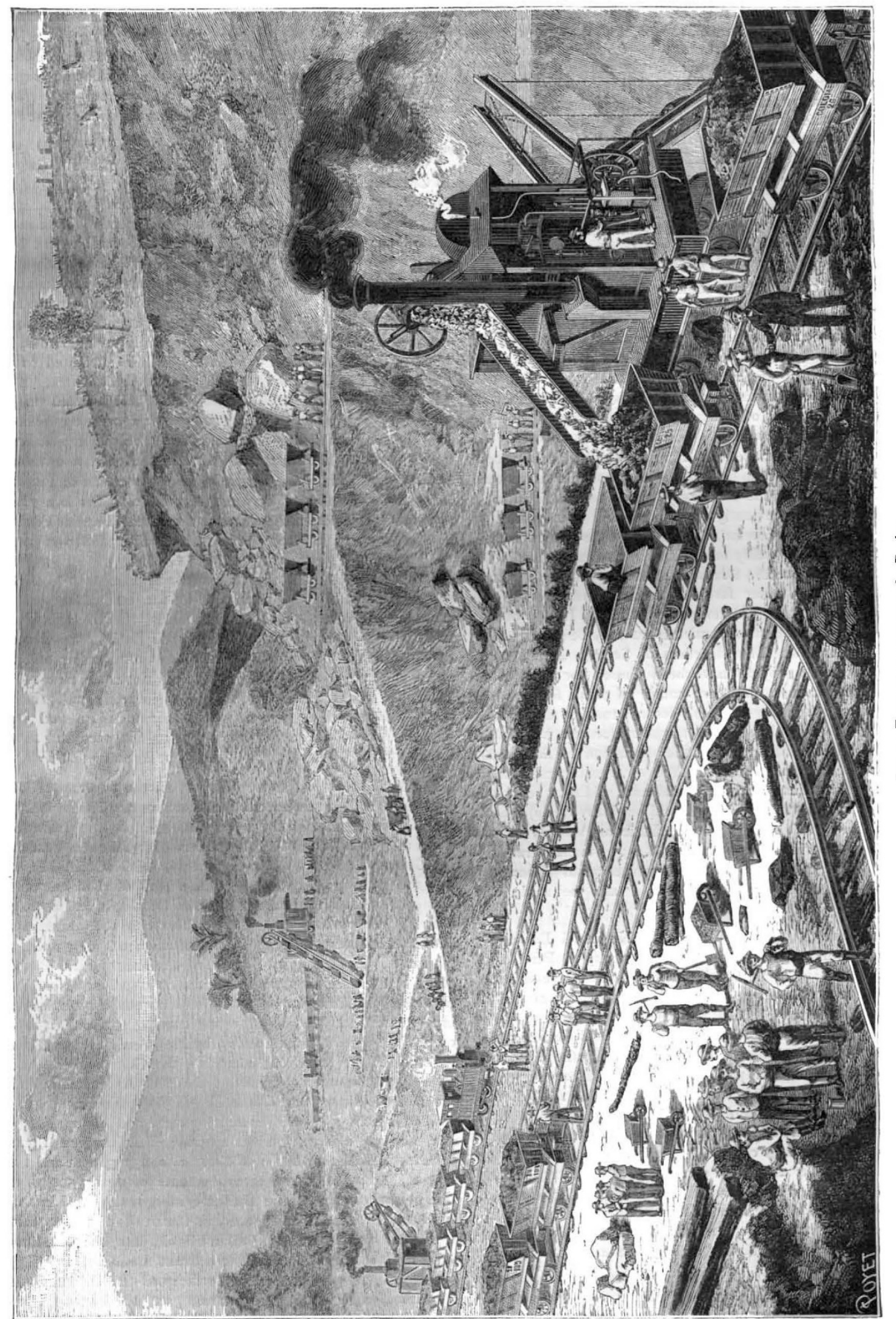


To sum up, more than two-thirds of the work of making the canal is now in execution, under formal engagements with contractors. The problem of the canal has been solved in principle. The period of installation or preparation has been succeeded by one of execution, based on a definitive programme, accepted by those who must carry it out, the Company itself maintaining an attitude of rigorous surveillance.

\section{NOTES}

THE fifty-eighth meeting of the German Association of Naturalists and Physicians will this year meet at Strassburg. Notices of communications and abstracts of papers should be sent to Herr J. Stilling. The meeting will commence on Thursday, September 17, and terminate on September 23,

THE local committee of the American Association has issued its second circular containing the general programme of the meeting at Ann Arbor. The meeting will be called to order on Wednesday, August 26, at 10 a.m., when Prof. Lesley will resign the chair to President- $\epsilon$ lect Prof. Newton of New Haven, and the usual addresses of welcome will be delivered. In the evening Prof. Lesley will give his presidential address. On Thursday evening the citizens of Ann Arbor will tender a reception at the Court House, and on Friday it is probable that a lawn party will be given on the University grounds. On Saturday a long excursion, as previously announced, will take place; on Monday a short excursion for the members of the Botanical Club has been planned, probably to the Tamarack swamp, one of the detached spots common in Southern Michigan where a northern flora has lingered under favourable conditions through the various climatic changes of later geologic times. It is probable that similar trips to points of local interest may be arranged for some of the sections. The chairman of Section $\mathrm{C}$ announces that the following subjects have been chosen for discussion: first, what is the best initiatory course of work for students entering upon laboratory practice? second, to what extent is a knowledge of molecular physics necessary for one who would teach theoretical chemistry? In the discussion in Section D, mechanical science, of the best method of teaching mechanical engineering, in order that what is read and said may be to the point, the following classification should be observed: $(a)$ schools of mechanical engineering; (b) mechanic art schools for the education of superintendents, foremen, \&c. ; $(c)$ manual trainingschools. The distinction between "mechanical laboratory practice" and "shop practice" should also be made and appreciated.

THERE seems to be no doubt that Sir Nathaniel Barnaby is about to close his connection with the Admiralty as Director of Naval Construction. We shall be interested to see in what manner the new Government fills up the vacancy, and what treatment they give Sir Nathaniel's successor, who, it is rumoured, may be Mr. W. H. White. As is known, Mr. White some time ago resigned his connection with the Admiralty for a far more lucrative post in Sir W. Armstrong's works. "But there is a difficulty in the way," as the Pall Mall Gazette puts it. "Private firms can pay, and do pay, their chief constructors twice, three, and four times as much as the Admiralty. Perhaps Mr. White may consent to sacrifice some thousands a year for the honour and glory of serving his country, but the time will come when scientific skill, like other commodities, will have to be purchased at the Admiralty at its market rate." Perhaps a Conservative Government will show itself more alive to this aspect of the post than its Liberal predecessor.

DR. Pagenstecher, of Hamburg, has just described a new form of Frugivorous Bats from a specimen transmitted to the Natural History Museum of that city by Herr H. Soyaux, of
Gaboon. Megaloglossus woermanni, as this new mammal is proposed to be called, is remarkable as belonging to the longtongued division of the Pteropine Bats, which was not previously known to occur anywhere within the Aithiopian region. Megaloglossus is closely allied to Macroglossus and Melonycteris, and in some characters is intermediate between these two genera. In its dentition it also exactly resembles them.

WE are informed by Dr. G. A. Guldberg, of the University of Christiania, that the fishery of rorquals or fin-whales (Balanoptere) established at Vadö in East Finmarken, for commercial purposes, continues to be turned to good account for scientific investigation. This year Dr. R. Collett, the well-known Norwegian naturalist, is visiting the place, and has already made many interesting observations upon the structure and habits of Rudolphi's whale (Balanoptera borealis), which has been captured in considerable numbers during the latter part of July, although the great blue whale ( $B$. sibbaldii), generally so numerous, has not yet been seen upon the coast. This is attributed to the absence of the Thyssanopoda inermis, a small crustacean on which the blue whale feeds. Rudolphi's whale is called "seje" or "cod" whale by the Norwegians, as it appears on the coast at the same time as that fish, but its food is also a crustacean of a still smaller species than that which is the chief nourishment of its gigantic relative. It usually visits the coasts of Finmark between the months of May and August, and has lately been taken several times on the east coast of Great Britain (Firth of Forth, 1872; River Crouch, Essex, November 1883; mouth of the Humber, September 1884). Dr. Guldberg gives its average length as 40 feet, but says it sometimes attains 50 feet. Its shape is more elegant than that of the commoner species, $B$. musculus, which it otherwise resembles. Its colour is black, and does not show the bluish tint seen in the latter species and in $B$. sibbaldii. The ;ides are spotted with white, and the under parts are white with a faint reddish tinge. A new use to which the whales killed at Vadö have been lately put is tinning their flesh, which is said to be wholesome, and to find great favour in Catholic countries, where, being fish according to the zoology of the Church, it is allowed to be eaten on fast days.

We have received the annual report for the past year of Prof. Spencer Baird, Secretary of the Smithsonian Institution. It includes an account of the work performed by the Institution itself, as well as that of the branches of the public service placed by Congress under its charge, namely, the National Museum and the Bureau of Ethnology. A sketch of the work of the United States Fish Commission and of the Geological Survey is added. We observe that the additions to the Museum are described as unexampled in extent, consequent partly upon the labours of the Geological Survey, of the Ethnological Bureau, of the first Commission, and of numerous miscellaneous explora. tions, both public and private. These various explorations are briefly described. Amongst the forthcoming publications is one on the Botany of North America, by Prof. Asa Gray, part II. o which is in the press. It comprises the Gamopetalous orders from Caprifoliacee to Composite inclusive. An enumeration by the author indicates that of the Caprifoliacea there are 8 genera and 47 species; of Rubiacea, 26 genera and 86 species; of Valerianacea, 2 genera and 22 species; of Dipsacacea, I genus and 2 species (naturalised); of Compositce, 237 genera and 1610 species. It will form an octavo volume of nearly 500 pages. The geological map of the United States, commenced in 1883 , has been completed and placed in the hands of the engraver. It was found, after collating all available data, that the knowledge acquired is not sufficient to warrant the extension of geological colours over the entire territory of the United States. Accordingly, California,'Oregon, and parts of Montana, Idaho, Nevada, Arizona, Utah, New Mexico, and Texas remain 